\title{
Long Term Protease Inhibitor Monotherapy in a Two-Tiered HIV-1 Levels Design
}

\section{Ernest ND ${ }^{1 *}$ and Michael $\mathbf{C}^{1,2}$}

${ }^{1}$ Research Service and Development, VA Medical Center, Irving Avenue Syracuse, NY, USA

${ }^{2}$ Department of Medicine, SUNY Upstate Medical University, Syracuse, NY, USA

\begin{abstract}
Treatment of choice in ART therapy for HIV-1 viremia remains an issue as all treatments interrupt HIV repopulation albeit at different reproductive points. The issue was addressed by grouping patients into two-tiered HIV level design of High $>50,000$ and Low $<50,000$ plasma $\mathrm{cps} / \mathrm{ml}$. The High group with 3 patients had combined class ART using NRTI plus NNRTI or PI regimens until viremia was reduced to $<75 \mathrm{cps} / \mathrm{ml}$ and then PI alone. The Low group with 11 patients had PIMT regimen. CD4 T cell levels were monitored throughout. ART efficacy was assessed as total number of months of controlled $(<75 \mathrm{cps} / \mathrm{ml})$ viral infection level vs. number of months of uncontrolled levels of $(>75 \mathrm{cps} / \mathrm{ml})$. In that adherence/non-adherence to regimen is a confound, it was also assessed by rate of suppression: $\mathrm{HIVj-HIVk/}$ $\mathrm{HVj-HVn}$. In the High group, one patient attained long term controlled HIV viremia over 56 months vs. 3 months of uncontrolled viremia while the other two patients ( 21 vs. $25 ; 9$ vs. 11) did not. Corresponding values in Group 2 ranged from 6 months to 139 months vs. $<5$ months A t-test for correlated means (with control for duration differences) showed significant difference: $t=4.10, \alpha=<0.01, d f=10$. Suppression rates, both within and across groups, were from: 0.99-1.0 of $\mathrm{cps} / \mathrm{ml}$. Accordingly, PI monotherapy can maintain long term viremia suppression for viral levels of $<50,000 \mathrm{cps} / \mathrm{ml}$ and ART is operative within an inferred functionally closed boundary system as no host characterization including CD4 T cell level affected ART outcome.
\end{abstract}

Keywords: HIV-1; PIMT; Pharmacotherapeutic; Efficacy; ART; Interaction; Efficacy

\section{Introduction}

The goal of antiretroviral therapy (ART) is long term suppression of HIV in plasma. Current standard recommended therapeutic options include use of protease inhibitor (PI) or non-nucleoside reverse transcriptase inhibitor (NNRTI) combined with two nucleoside reverse transcriptase inhibitors (NRTI) for high viral loads $(>75,000$ $\mathrm{cps} / \mathrm{ml}$ ) as well as for long term maintenance at $<40 \mathrm{cps} / \mathrm{ml} \mathrm{[1].} \mathrm{Using}$ protease inhibitors in combination with NNRTI can be problematic due to potential development of drug resistance and consequent loss of treatment options [1-4]. Recent licensure of many alternative drugs targeting protease and reverse transcriptase as well as newer class inhibitors such as INSTI (integrase inhibitors) and CCR5 (co-receptor blocker) provide effective counters to resistance as well as to other untoward side effects.

The need for life long therapy for HIV infection includes the potential risk of drug toxicities, drug interactions and high maintenance costs particularly in developed countries around the globe. Several randomized clinical trials examined the efficacy of PIMT (protease inhibitor monotherapy [4-9]. Reviews of the literature, however, show lack of agreement on PIMT efficacy [10-14]. Following an earlier study Paton [15] examined this issue with a TR (truly random) non-inferiority study comparing standard combined class inhibitor regimens vs. single class protease inhibitor regimens for long term maintenance of suppression at $<50 \mathrm{cps} / \mathrm{ml}$. The results confirmed both the expectation of PIMT efficacy for long term suppression and that of showing non-inferiority of PIMT on rebound frequency, loss of treatment option, as well as drug intolerance and toxic effects in comparison with combined class therapy. Altogether, the results of at least these two studies suggest that PI monotherapy might be the way forward for maintaining sustained HIV-1 suppression [16,17].

The present two-tiered retrospective study was designed to assess the efficacy of combined class ART using NRTI plus NNRTI or PI regimens followed by PI regimen to attain and maintain suppression $(<75 \mathrm{cps} / \mathrm{ml}$ ) for starting viral loads of $>50,000 \mathrm{cps} / \mathrm{ml}$ in one group; and, in a second group, by using PI regimens for starting viral loads of $<50,000 \mathrm{cps} / \mathrm{ml}$. The specific issue addressed was whether $<50,000 \mathrm{cps} /$ $\mathrm{ml}$ viral load levels could be suppressed and sustained by PI regimen on a long term basis. Simply put, is $<50,000 \mathrm{cps} / \mathrm{ml}$ the new threshold at which PI regimens alone could both attain and sustain long term suppression of HIV viral load?

\section{Materials and Methods}

\section{Patients}

Fourteen patients comprised the present retrospective study. Upon inspection of patient records, no host characterization variables were observed to contribute to ART efficacy; i.e., age, comorbidity and other state of health monitors. This outcome, therefore, did not provide a rational basis for a need to randomize patients into assigned groups. Patient assignment was based on initial pretreatment HIV plasma viral load levels (cps/ml). Accordingly, two treatment groups were formed from the HIV outpatient population in the VA Medical Center at Syracuse, NY: Group I, high $>50,000 \mathrm{cps} / \mathrm{ml}$; and, Group II, low $<50,000 \mathrm{cps} / \mathrm{ml}$ of plasma HIV.

*Corresponding author: Ernest ND, Research Service and Development (151) VA Medical Center, 800 Irving Avenue Syracuse, NY 13210d, USA, Tel: 315 4254865; E-mail: damianopoulos@gmail.com

Received September 12, 2016; Accepted September 24, 2016; Published September 30, 2016

Citation: Ernest ND, Michael C (2016) Long Term Protease Inhibitor Monotherapy in a Two-Tiered HIV-1 Levels Design. J AIDS Clin Res 7: 619. doi:10.4172/21556113.1000619

Copyright: ( 2016 Ernest ND, et al. This is an open-access article distributed under the terms of the Creative Commons Attribution License, which permits unrestricted use, distribution, and reproduction in any medium, provided the original author and source are credited. 


\section{ART regimens}

Combined class treatment regimen was used for patients with high HIV viral load levels starting at $>50,000 \mathrm{cps} / \mathrm{ml}$ plasma RNA HIV viral loads until viremia was suppressed to $>75 \mathrm{cps} / \mathrm{ml}$. It was then followed by PIMT for maintenance of the suppressed viremia. For patients in the Low group $(<50,000 \mathrm{cps} / \mathrm{ml})$, PIMT was used throughout except when resistance would occur and then the treatment was switched to another PI drug; or, if PI options were lost altogether, to a combined multiclass regimen.

In the Low Group, of the 11 patients one had a 3NRTI regimen; and, one other patient had a 2NRTI/1NNRTI combination treatment prior to initiation of the PI regimen. Patient appointments (observation intervals) were within a range of one to six months; and, rarely, only one week apart. HIV viral loads were monitored throughout to chart viremia suppression as well as co-morbidities such as: hepatitis C, cancer, renal failure requiring dialysis and others.

\section{Treatment efficacy assessments}

The number of months of controlled viremia $(<75 \mathrm{cps} / \mathrm{ml})$ vs. number of months of uncontrolled viremia $(>75 \mathrm{cps} / \mathrm{ml})$ was one measure of efficacy. However, given the inherent confound of adherence/non-adherence in this measure, a second direct measure was used, not found in the extant literature. This was the rate measure of suppression expressed as a mathematical ratio of differences. When applied to HIV-1 viremia, it would take the form: HIVj-HIVk/HIVjHIVn where the two numerator values of HIVj and HIVk represent plasma viral load levels (cps/ml) at first and second observations; whereas, the denominator value of HIVj-HIVn represents the total unsuppressed viral load $(\mathrm{cps} / \mathrm{ml})$. That is, treatment effect in the formula above shows partial/over total possible reduction of $\mathrm{cps} / \mathrm{ml}$ at any period of the regimen.

\section{Resistance mutations and CD4 T cell levels}

Resistance mutations were documented as they occurred. Patients showing resistance were switched to an alternative drug from the same class. When there were no options left, the switch was to a combined multiclass 2NRTI/1NNRTI regimen. CD4 T cell levels were monitored throughout; but, as CD4 T cell count levels appeared to be unrelated to treatment efficacy, they were monitored only intermittently in the last two years.

\section{Results}

\section{Group I high HIV viral level $>50,000 \mathrm{cps} / \mathrm{ml}$}

Table 1 shows patient ID, age, co-morbidity and other patient characteristics for Group I, including treatment and outcome as well as current health status of the patient. Observation intervals were from 1 to 4 months As can be seen from Table 1, when PI therapy was started, following the initial multiclass combined treatment, the controlled levels of HIV $(<75 \mathrm{cps} / \mathrm{ml})$ were sustained over a long duration: 53 months vs. 3 months for patient 1 ; but, not for patients 2 and 3 . The corresponding results were: 21 vs. 25 and 9 vs. 11 months, respectively. Patient 2 was poorly adherent; and, not surprisingly, developed resistance. He was off therapy for 2 years; but, was suppressed on the subsequent PI regimen for almost 4 years at which point he required more intensive treatment regimen. Patient 3 developed resistance to atazanavir and was then treated with rilpivirine, tenofovir and emtricitabine.

Suppression rate, the second measure calculated as a ratio of differences, indicated high efficacy; i.e., rates of suppression ranged from $0.99-1.00$ of the available $\mathrm{cps} / \mathrm{ml}$ without variation, either within or across patients. These results showing high ART efficacy with both measures were immediate and there was no evidence of change; nor, of progressive additive ART effects over time.

\section{Group II low HIV viral level $<50,000 \mathrm{cps} / \mathrm{ml}$}

Table 2 shows patient information, treatment and treatment outcome results for Group 2. As can be seen from Table 2, all patients attained long term controlled HIV load levels of $<75 \mathrm{cps} / \mathrm{ml}$ over the course of treatment vs. $<5$ months of uncontrolled levels except for one patient who did respond to ART and did show periods of suppression; but who, nonetheless, did not attain long term sustained suppression with either ATZ/r (atazanavir/ritonavir), DAR/r (darunavir/ritonavir);

\begin{tabular}{|c|c|c|c|c|c|c|c|c|c|}
\hline Patient & Age & Co-morbidity & Prior Regimen & $\begin{array}{c}\text { Current } \\
\text { Regimen }\end{array}$ & $\begin{array}{l}\text { Highest VL copies/ } \\
\text { ml before PIMT }\end{array}$ & $\begin{array}{l}\text { Duration on PIMT } \\
\text { regimen }\end{array}$ & Current VL & $\begin{array}{l}\text { Current } \\
\text { CD4 }\end{array}$ & Outcome and Present Status \\
\hline 1 & 77 & Hep C- Cancer & $\begin{array}{c}\text { EMT/TEN } \\
\text { ATZ/r }\end{array}$ & ATZ/r & 177,800 & $\begin{array}{c}56 \mathrm{M} \\
\text { Controlled } \\
53 \text { Uncontrolled } 3\end{array}$ & $<1$ & $331(29)$ & $\begin{array}{c}\text { Well suppressed on prior regimen } \\
\text { EMT/TEN. } \\
\text { Discontinued due to elevated } \\
\text { creatinine }\end{array}$ \\
\hline 2 & 64 & Hep C+ & $S T A+L A M+A B C$ & $\begin{array}{l}\text { TIP/r } \\
\text { RAL } \\
\text { TEN }\end{array}$ & 56,209 & $\begin{array}{c}46 \mathrm{M} \\
\text { Controlled } \\
21 \\
\text { Uncontrolled } \\
25\end{array}$ & 46 & $393(26)$ & $\begin{array}{l}\text { Poorly adherent patient. } \\
\text { Previously on } 3 \text { NRTI's. He } \\
\text { developed resistance to NRTI's } \\
\text { and then stopped therapy for } \\
2 \text { years. After, he remained } \\
\text { suppressed on LOP/r for almost } 4 \\
\text { years; then showed poor control } \\
\text { of viral load and was switched } \\
\text { to DAR/r without improvement. } \\
\text { Viral load suppressed on present } \\
\text { regimen for several years }\end{array}$ \\
\hline 3 & 57 & Hep C- & $\mathrm{LOP} / \mathrm{r}$ & $\begin{array}{l}\text { RIL } \\
\text { EMT } \\
\text { TEN }\end{array}$ & 53100 & $\begin{array}{c}20 \mathrm{M} \\
\text { Controlled } 9 \\
\text { Uncontrolled } 11\end{array}$ & 277 & $439(20)$ & $\begin{array}{l}\text { Well suppressed before changing } \\
\text { the regimen. Intermittently } \\
\text { suppressed while on PIMT; } \\
\text { however, he developed resistance } \\
\text { to ATZ. } \\
\text { Since starting rilpivirine/EMT/TEN, } \\
\text { he has been suppressed for } 30 \\
\text { months }\end{array}$ \\
\hline
\end{tabular}

Note: EMT/TEN: Emtricitabine/Tenofovir; ATZ/R: Atazanavir/Ritonavir; STA: Stavudine; LAM: Lamivudine; ABC: Abacavir; DAR/r: Darunavir/Ritonavir; TIP/r: Tipranavir/ Ritonavir; RAL: Raltegravir; LOP/r: Lopinavir/Ritonavir; RIL: Rilpivinavir

Table 1: Antiretroviral efficacy of protease inhibitor monotherapy (PIMT) for patients with high initial viral load $>50000 \mathrm{cps} / \mathrm{ml}$. 
Citation: Ernest ND, Michael C (2016) Long Term Protease Inhibitor Monotherapy in a Two-Tiered HIV-1 Levels Design. J AIDS Clin Res 7: 619. doi:10.4172/2155-6113.1000619

Page 3 of 5

\begin{tabular}{|c|c|c|c|c|c|c|c|c|c|}
\hline Patient & Age & Co-morbidity & Prior Regimen & $\begin{array}{l}\text { Current } \\
\text { Regimen }\end{array}$ & $\begin{array}{l}\text { Highest VL copies/ } \\
\text { ml before PIMT }\end{array}$ & $\begin{array}{c}\text { Duration on PIMT } \\
\text { regimen }\end{array}$ & $\begin{array}{c}\text { Current } \\
\text { VL }\end{array}$ & $\begin{array}{l}\text { Current } \\
\text { CD4 }\end{array}$ & $\begin{array}{c}\text { Outcome and Present } \\
\text { Status }\end{array}$ \\
\hline 1 & 62 & Hep C+ & $\mathrm{STA}+\mathrm{TEN}+\mathrm{LAM}$ & ATZ/r & 43100 & $\begin{array}{c}142 \mathrm{M} \\
\text { Controlled } \\
139 \\
\text { Uncontrolled } \\
3\end{array}$ & $<1$ & $386(14)$ & $\begin{array}{l}\text { Started to simplify } \\
\text { therapy } \\
\text { Well suppressed }\end{array}$ \\
\hline 2 & 44 & Hep C- & $\begin{array}{c}\text { ZDV } \\
+ \text { LAM +TEN }\end{array}$ & ATZ/r & 14951 & $\begin{array}{c}72 \mathrm{M} \\
\text { Controlled } \\
71 \\
\text { Uncontrolled } \\
1\end{array}$ & $<1$ & $225(37)$ & Well suppressed \\
\hline 3 & 56 & Hep C- & Naive & ATZ/r & 17970 & $\begin{array}{c}18 \mathrm{M} \\
\text { Controlled } \\
18 \\
\text { Uncontrolled } \\
0\end{array}$ & $<40$ & $1167(30)$ & $\begin{array}{l}\text { Doing well on PIMT } \\
\text { regimen }\end{array}$ \\
\hline 4 & 60 & $\begin{array}{l}\text { Hep C+ } \\
\text { Prostate } \\
\text { cancer }\end{array}$ & Naive & ATZ/r & 10905 & $\begin{array}{c}79 \mathrm{M} \\
\text { Controlled } \\
79 \text { Uncontrolled } \\
0\end{array}$ & 91 & $303(16)$ & $\begin{array}{l}\text { Doing well on PIMT } \\
\text { regimen }\end{array}$ \\
\hline 5 & 64 & Hep C+ & Naive & $\mathrm{LOP} / \mathrm{r}$ & 42700 & $\begin{array}{c}34 \mathrm{M} \\
\text { Controlled } \\
31 \\
\text { Uncontrolled } \\
3\end{array}$ & $<75$ & $358(32)$ & $\begin{array}{c}\text { Achieved suppression } \\
\text { while on chronic dialysis. } \\
\text { Dead due to cardiac } \\
\text { failure }\end{array}$ \\
\hline 6 & 53 & Hep C- & Naive & $\mathrm{DAR} / \mathrm{r}$ & 26800 & $\begin{array}{c}74 \mathrm{M} \\
\text { Controlled } \\
4 \\
\text { Uncontrolled } \\
70\end{array}$ & 84 & $540(25)$ & $\begin{array}{l}\text { Chronic dialysis; patient } \\
\text { started on LOP/r. } \\
\text { Switched to ATZ/r } \\
\text { then DAR/r due to } \\
\text { failure to achieve viral } \\
\text { suppression }\end{array}$ \\
\hline 7 & 62 & Hep C- & Naive & $\mathrm{DAR} / \mathrm{r}$ & 23777 & $\begin{array}{c}78 \mathrm{M} \\
\text { Controlled } \\
74 \\
\text { Uncontrolled } \\
4\end{array}$ & $<1$ & 443 (19) & $\begin{array}{l}\text { Achieved suppression } \\
\text { with } D A R / r\end{array}$ \\
\hline 8 & 43 & Hep C- & Naive & ATZ/r & 48756 & $\begin{array}{c}16 \mathrm{M} \\
\text { Controlled } \\
16 \\
\text { Uncontrolled } \\
0\end{array}$ & 43 & $689(44)$ & Suppressed on ATZ/r \\
\hline 9 & 53 & Hep C- & $\begin{array}{l}\text { ZDV } \\
\text { LAM } \\
\text { ABC }\end{array}$ & ATZ/r & 28944 & $\begin{array}{c}58 \mathrm{M} \\
\text { Controlled } \\
58 \\
\text { Uncontrolled } \\
0\end{array}$ & $<1$ & $516(50)$ & Suppressed on ATZ/r \\
\hline 10 & 65 & $\begin{array}{l}\text { Hep C- } \\
\text { Anal } \\
\text { cancer } \\
\text { diabetes }\end{array}$ & Naive & ATZ/r & 17500 & $\begin{array}{c}30 \mathrm{M} \\
\text { Controlled } \\
25 \\
\text { Uncontrolled } \\
5\end{array}$ & $<1$ & $780(27)$ & $\begin{array}{l}\text { Initially non-adherent; } \\
\text { however, when he } \\
\text { became adherent, ATZ/r } \\
\text { suppressed his viral load }\end{array}$ \\
\hline 11 & 60 & $\begin{array}{l}\text { Hep C- } \\
\text { diabetes }\end{array}$ & Naive & ATZ/r & 17970 & $\begin{array}{c}9 \mathrm{M} \\
\text { Controlled } \\
6 \\
\text { Uncontrolled } \\
3\end{array}$ & $<40$ & $1167(30)$ & Suppressed on ATZ/r \\
\hline
\end{tabular}

Note: ATZ/R: Atazanavir/Ritonavir; STA: Stavudine; LAM: Lamivudine; ABC: Abacavir; DAR/R: Darunavir/Ritonavir; LOP: Lopinavir/Ritonavir

Table 2: Antiretroviral efficacy of protease inhibitor monotherapy (PIMT) for patients with low initial viral load $<50000 \mathrm{cps} / \mathrm{ml}$.

nor, with the earlier LOP/r (lopanavir/ritonavir) regimen. However, the patient did claim adherence throughout. A test for drug resistance mutations was negative; but, the test was performed early in the course of treatment. In spite of failure to achieve sustained viral suppression, he was asymptomatic regarding his HIV infection for 6 years with a viral loads usually below $500 \mathrm{cps} / \mathrm{ml}$ and a stable $>200 \mathrm{CD} 4 \mathrm{~T}$ cell count; altogether a stable, sustainable and tolerable outcome. A t-test for correlated means of controlled and uncontrolled number of months (following transformation into unit normal scores to control for treatment duration differences) indicated a statistically significant effect of PIMT regimen in controlling HIV-1 levels at $<75 \mathrm{cps} / \mathrm{ml}$ : $\mathrm{t}=4.10, \alpha=<0.01, \mathrm{df}=10$.

Rate of viral load suppression was also assessed with the standard rate formula described above. As in Group I, the values for the first and second assessment again showed a high rate of suppression ranging from $0.99-1.00$ of the available $\mathrm{cps} / \mathrm{ml}$, except for the one patient who did not achieve sustained suppression; but who, nonetheless, showed rate scores of $0.98,0.98$ and 1.00 . Observation intervals ranged from 
1-5 months although one patient had not been seen over a period of 6 months with no impact on rate scores.

The high ART efficacy rate observed in Group II is consistent with the results for Group I that had the combined multiclass treatment regimens of NRTI, NNRTI and PIMT. Accordingly, this observed convergence in outcome in spite of treatment differences, leaves the question of choice of combined vs. single class regimens on factors other than treatment efficacy; both were equally effective. Moreover, the ART effects were immediate, not additive, and sample size did not matter as illustrated by the sample size differences between Group I and Group II with no differential impact on the treatment efficacy. This last observation has some relevance and significance.

\section{CD4 $t$ assessment and ART efficacy}

CD4 t levels were without impact and showed no consistent pattern in relation to ART efficacy over the longitudinal treatment time line. A correlational analysis in relation to reduction of HIV viral load was not carried out in view of the fact that CD4 $t$ was monitored only intermittently in the last 2 years

\section{Discussion}

The results, overall, of the fourteen patients, with one exception, suggest that the two-tiered treatment strategy of categorizing patients into high $(>50,000 \mathrm{cps} / \mathrm{ml})$ and low HIV $(<50,000 \mathrm{cps} / \mathrm{ml})$ viral load levels was sustained. The question whether $<50,000 \mathrm{cps} / \mathrm{ml}$ is susceptible to PIMT and thus becoming the new upper threshold for PIMT was also answered by positive result outcomes. Drug resistance was detected in two instances of the first group $(<50,000 \mathrm{cps} / \mathrm{ml})$; and, this is consistent with earlier expectations [18].

In conclusion, PIMT should be considered as a potential option for maintaining suppressed HIV viral load levels even for thresholds as high as $<50,000 \mathrm{cps} / \mathrm{ml}$ ) once suppression is achieved by combined multiclass regimen. In instances of patients of low initial viremia levels, PIMT might be an effective choice to attain and sustain suppressed viremia starting at threshold levels as high as $<50,000$ in place of the current standard $<50 \mathrm{cps} / \mathrm{ml}[14,15]$.

The significance of the CD4 T cell count, which varied among patients, is that this is the only functional point of contact of host to HIV virus. It was, however without impact on treatment outcome what this last observation suggests is that patient variability in age and other state of health monitors play no role in the HIV viral load level $\times$ ART efficacy interaction; thus, eliminating the need for randomization of patient assignment into treatment groups. Instead, the significance of the CD4 T observed lack of effect on treatment outcome lies in the parametric limitations it places on the interpretation of the treatment $\mathrm{x}$ HIV interaction outcome.

Regarding the issue of choice of drug regimen, the observed results allow no precise rational basis for choice as shown by the high and equal ART efficacy rate (0.9-1.0 kill rate of $\mathrm{cps} / \mathrm{ml}$ ) for both combined class as well as PI monotherapy within and across patients; thus, factors other than efficacy would determine choice (economic cost, adherence, tolerance, toxicity, and other side effects).

The present results can be conceptualized as falling into a framework model consisting of two domains (or systems). The first domain is the interactive plasma HIV viral load $\times$ ART that is operative within a functionally closed boundary system [19] in which no exteroceptive environmental or interoceptive host patient characterizations such as age, co-morbidities, Hepatitis $\mathrm{C}$, cancer, renal deficits, etc. impact upon the HIV load level $\times$ ART interaction efficacy. This is indirectly supported by the observation of high ART efficacy in the two outcome measures regardless of combined or single class therapy regimens. The second domain is the integrated HIV genome into the memory CD4 T cells Here, ART is ineffective as the HIV virus in the memory CD4 T cells is stable and remains in a non-replicative state [20-22].

Certain expectations follow from the above conceptualization of the present findings: (1) random assignment in research studies of patients to ART treatment is not necessary; (2) ART efficacy rate constant within and across groups $(\mathrm{k}=0.99-1.0)$ suggests a marker for objective determination of adherence/non-adherence in patients and as an independent check on patient self-reports. (3) If ART treatment is effective in one patient, it will be effective in other patients, save for drug resistant HIV mutation and/or non-adherence. (4) Cohort size in ART efficacy studies is irrelevant except for long term observation of resistance, side effects and/or non-adherence (5). Patient differences in response to drug regimens are largely due to side effects and/or differences in drug absorption. (6) Considerable economy in lifetime treatment costs in the developed world is likely were conclusion (4) sustained by further studies.

\section{References}

1. Thompson MA, Aberg JA, Hoy JF, Telenti A, Benson C, et al. (2012) Antiretroviral treatment of adult HIV infection. JAMA 308: 387-402.

2. Paton NI, Stöhr W, Oddershede L, Arenas-Pinto A, Walker S (2016) The protease inhibitor monotherapy versus ongoing triple therapy (PIVOT) trial: A randomised controlled trial of a protease inhibitor monotherapy strategy for long-term management of human immunodeficiency virus infection. Health Technol Assess 20: 1-158.

3. Arribas JR, Delgado R, Arranz A, Muñoz R, Portilla J, et al. (2009) Lopinavirritonavir monotherapy versus lopinavir-ritonavir and 2 nucleosides for maintenance therapy of HIV: 96-week analysis. J Acquir Immune Defic Syndr 51: 147-152.

4. Maggiolo F, Revasio L, Ripmonti D, Gregis G, Quinzan G, et al. (2005) Similar adherence rates favor different virological outcomes for patients treated with non-nucleoside analogues or protease inhibitors. Clin Infect Dis 40: 158-163.

5. Paquet AC, Evans MC, Whitcomb J (2011) Significant reductions in the prevalence of protease inhibitor and class resistance: Recent trends in large HIV-1 protease/reverse transcriptase data base. CAAC.

6. Girouard MP, Sax PE, Parker RA, Taiwo B, Freedberg KA, et al. (2016) The cost-effectiveness and budget impact on 2-drug dolutegravir-lamivudine regimens for the treatment of HIV infection in the United States. Clinical Infectious Diseases 62: 784-791.

7. Harries AD, Zachariah R, van Oosterhaout JJ (2010) Diagnosis and management of antiretroviral therapy failure in resource limited settings in subSahara Africa: Challenges and perspectives. The Lancet Infectious Diseases 110: 60-65.

8. Pulido F, Arribas JR, Delgado R, Cabrero E, González-García J, et al. (2008) Lopinavir-ritonavir monotherapy versus Lopinavir-ritonavir and nucleosides for maintenance of therapy of HIV. AIDS 22: F1-F9.

9. Katlama C, Valantin MA, Algarte-Genin M, Duvivier C, Lambert-Niclot S, et al. (2010) Efficacy of darunavir/ritonavir maintenance monotherapy in patients with HIV-1viral suppression: A randomized open-label non-inferiority trial, MONOI-ANRS. AIDS 24: 2365-2374.

10. Ndemi N, Goodall RL, Dunn MT, McCormick A, Burke A, et al. (2010) Vira rebound and the emergence of drug resistance in the absence of viral load testing: A randomized comparison between zidovudine-lamivudine plus nevirapine and zidovudine-lamivudine plus abacavir. J Infect Dis 201: 106-113.

11. Bierman WFF, van Agtamael MA, Nijuis M, et al. (2009) HIV monotherapy with ritonavir-boosted inhibitors: A systematic review. AIDS 23: 279-291.

12. Vernazza PS, Daneel V, Schiffer L, Decosterd L, Fierz W, et al. (2007) The role of compartmental penetration in PI-monotherapy: The atazanavir-ritonavir monomaintenance (ATARITMO) trial. AIDS 21: 1309-1315.

13. Jilek BL, Zarr M, Sampah ME, Rabi SA, Bullen CK, et al. (2012) A quantitative basis for antiretroviral therapy for HIV-1 infection. Nature Medicine 18: 446-451. 
Citation: Ernest ND, Michael C (2016) Long Term Protease Inhibitor Monotherapy in a Two-Tiered HIV-1 Levels Design. J AIDS Clin Res 7: 619. doi:10.4172/2155-6113.1000619

Page 5 of 5

14. Ghosn J, Slama L, Chermak A, Houssaini A, Lambert-Niclot S, et al. (2013) Switching to darunavir/ritonavir $800 / 100 \mathrm{mg}$ once daily containing regimen maintains virological control in fully suppressed pre-treated patients infected with HIV-1. J Med Virol 85: 8-15.

15. Paton IN, Stohr W, Arenal-Pinto A, Fisher M, Williams I, et al. (2015) Protease inhibitor therapy for long-term management of HIV infection: A randomized, controlled, open-label, non-inferiority trial. Lancet HIV.

16. Calmy A, Sullier D (2015) Is monotherapy maintenance the way forward? The Lancet HIV 2: e402-e403.

17. Perez-Valero I, Bayon C, Cambron I, Gonzalez A, Arribas JR, et al. (2011) Protease inhibitor monotherapy and the CNS: peace of mind? J Antimicrobal Chemotherapy 66: 1954-1962.
18. Clavel F (2004) Mechanisms of HIV drug resistance: A primer. The PRN Notebook 9 .

19. Bergmann G (1957) Science. University of Wisconsin Press, Madison, WI

20. Siliciano JM, Siliciano RF (2015) The remarkable stability of the latent reservoir for HIV-1 in resting memory CD4 ${ }^{+} \mathrm{T}$ cells. The Journal of Infectious Diseases 212: $1345-1347$.

21. Ahallenstiehl CL, Suzuki K, Marks K, Symonds GP, Kelleher AD, et al. (2015) Controlling HIV-1: Non-coding RNA gene therapy approaches to a functional cure. Front Immunol 6: 474 .

22. Tang X, Liang Y, Liu X, Zhou S, Liu L, et al. ( 2015) PLGA-PEG nanoparticles coated with anti-CD45RO and loaded with HDAC plus protease inhibitors activate latent HIV and inhibit viral spread. Nanoscale Res Lett Dec 19: 43. 